\title{
A UTILIZAÇÃO DO CONHECIMENTO DE PLANTAS MEDICINAIS COMO FERRAMENTA PARA ESTIMULAR A PRESERVAÇÃO AMBIENTAL
}

\author{
Marizelda Rael da Silva* \\ *Bióloga - CRBIO - 03: 58039-03D \\ Acadêmica de Especialização em Educação Ambiental/UFSM \\ e-mail: $\underline{\text { marizeldarael@bol.com.br }}$
}

\section{Resumo:}

Este estudo tem o objetivo de identificar o nível de conhecimento sobre plantas medicinais na comunidade escolar onde está inserida a Escola Municipal de Ensino Fundamental Aldo Porto dos Santos e sua relação com a Educação Ambiental, transformando essas informações numa ferramenta para introdução da Educação Ambiental. Para tanto, aborda-se o uso de plantas medicinais discorrendo desde a origem da fitoterapia, a história do relacionamento das pessoas com as plantas desde os tempos pré-históricos até o presente, as propriedades das ervas medicinais, maneiras de melhor aproveitar suas propriedades e os cuidados que devem ser tomados durante o emprego das mesmas. Para realizar a primeira etapa do trabalho foi aplicada uma pesquisa quantitativa através de um questionário que foi respondido por cento e onze pessoas. Na segunda etapa do projeto foi elaborado o "relógio das plantas medicinais" da qual participou a turma do 60 ano constituída por vinte alunos contando com a colaboração da comunidade escolar que ajudou na obtenção das espécies das plantas estabelecidas. Avaliando os resultados do projeto e comparando com o objetivo proposto foi possível constatar que na referida comunidade escolar há um conhecimento razoável das plantas medicinais e que as plantas usadas são cultivadas nos próprios quintais de suas casas seguindo a cultura local. Concluise desta forma que há vários métodos para atingir os objetivos relacionados ao desenvolvimento da Educação Ambiental, mas que esta ação tem melhor resultado quando está apoiada nos interesses comuns do grupo e no conhecimento e experiência cultural já existente.

Palavras-chave: Educação Ambiental; Plantas Medicinais; Cultura.

\section{ABSTRACT}

This work has the objective of identifying the level of knowledge about medicinal plants in the school community where is inserted the municipal elementary school Aldo Porto dos Santos and it relationship with Environmental Education, turning that information into a tool of introduction to Environmental Education. For that, was covered the origin of phytotherapy, the history of the relationship of the people with the plants since the prehistoric times until the present, the proprieties of the medicinal herbs, ways for better utilize their proprieties and the cares that must be taken during the usage of them. To realize the first stage of this work it was applied a quantitative research through a questionnaire which was answered by one hundred and eleven people. In the second stage of the project it was labored the "clock of medicinal plants" which was attended by the 6th grade class composed of twenty students counting with the collaboration of the scholar community which helped in obtaining the established species of plants. Evaluating the results of the project and comparing with the proposed objective it was possible to note that in the said school community there is a reasonable knowledge of the medicinal plants and that the 
used plants are cultivated in their own yards of their homes following the local culture. Concludes in this way that there are several methods to achieve the objectives related to the development of the Environmental Education, but this action have better result when it's supported in the common interests of the group and in the knowledge and cultural experience that already exists.

Keywords: Environmental Education; Medicinal Plants; Culture.

\section{INTRODUÇÃO}

Na construção da nossa história as relações entre os homens e a natureza, inseridos numa cultura que cria, recria, elabora e re-elabora constantemente, tem como resultado uma natureza que não é mais natural. Portanto se faz necessário que os educadores propaguem em suas escolas e na comunidade, o que a educação ambiental ensina sobre o funcionamento e equilíbrio da natureza. Rosa (1998) afirma que o cidadão que deseja assegurar um planeta equilibrado e sustentável para as próximas gerações tem por obrigação compreender como os elementos da natureza têm reagido diante das ações da humanidade sobre ele.

A retomada desse equilíbrio aponta para mudanças, formando novos padrões de comportamento e valores frente a este desafio. Segundo a Lei 9.795, de 27 de abril de 1999, a Educação Ambiental, é um componente essencial e permanente da educação Nacional, devendo estar presente em todos os níveis e modalidades do processo educativo formal e não-formal (BRASIL, 1999).

Percebe-se a importância desses programas, no entanto, os educadores precisam ter sempre presente que educação ambiental exige mais, ou seja, deve despertar a comunidade escolar para questões mais amplas, focadas na biodiversidade em que se vive. Assim, conhecer a biodiversidade, procurando utilizá-la com respeito, parcimônia e racionalidade é um bom começo e é por meio da educação ambiental que se adquiri esse conhecimento, através de um processo pedagógico participativo e permanente, o qual procura sensibilizar tanto o educando quanto a comunidade, promovendo o desenvolvimento de atitudes necessárias à preservação, à prevenção e à melhoria da qualidade de vida.

É neste contexto que está inserida a utilização do conhecimento de plantas medicinais como ferramenta para estimular a preservação ambiental, pois quando se realiza estudos pedagógicos sobre plantas medicinais, tanto se trabalha a temática do meio ambiente, quanto à orientação sobre economia, saúde e qualidade de vida criando-se um elo entre Educação Ambiental e Saúde Pública, e a escola deve aproveitar essa ferramenta e orientar os alunos a respeito das riquezas dos recursos naturais despertando neles o fascínio pela pesquisa das propriedades medicinais das plantas e sua correta aplicação terapêutica, pois as plantas medicinais surgem como uma das alternativas para o trabalho preventivo da saúde da pessoas (SILVEIRA, 2005).

Frente a essa constatação e com o propósito educacional desenvolveu-se esse estudo sobre o uso das plantas medicinais. Abordando-se a origem da fitoterapia, a história do relacionamento das pessoas com as plantas desde os tempos pré-históricos até o presente, as propriedades das ervas medicinais, maneiras de melhor aproveitar suas propriedades e os cuidados que devem ser tomados durante o emprego das mesmas. Para tanto utilizou-se, por 
meio de pesquisa, o conhecimento de cientistas, historiadores, antropólogos e outros que exploram os mundos da botânica e da medicina.

Caravaca (2000) comenta que cada povo possui sua própria lista de ervas medicinais, plantas comuns típicas da região em que vivem e das quais o emprego é transmitido de geração a geração. A natureza dispõe de todos os benefícios para tratar e auxiliar as pessoas na cura dos males. São tantas as possibilidades que podem ser extraídas dela que, por vias distintas, muitos químicos ou farmacêuticos encontram nos produtos naturais, seu objeto de estudo, mas ainda hoje se observa a utilização das plantas medicinais como uma medicina alternativa ou complementar aos recursos terapêuticos alopáticos.

Quanto à evolução do uso de fitoterápicos Lorenzi (2002) afirma que o emprego de plantas medicinais na recuperação da saúde tenha evoluído ao longo dos tempos desde as formas mais simples de tratamento local, provavelmente utilizada pelo homem das cavernas, até as formas tecnologicamente sofisticadas da fabricação industrial utilizada pelo homem moderno. Por outro lado, Veiga Junior et al. (2005), declara que na atualidade é cada vez mais freqüente o uso de plantas medicinais oriundas das medicinas orientais e que geralmente são desconhecidas do povo brasileiro, mas o comércio dessas plantas é sustentado por propagandas que prometem "benefícios seguros, por serem naturais" e na maioria das vezes as supostas propriedades farmacológicas divulgadas nem possuem validade científica, por não terem sido pesquisadas, ou por não terem tido seu efeito farmacológico comprovado, oferecendo dessa forma, risco à saúde pública ao invés de beneficio. $O$ autor ainda afirma que é motivo de preocupação saber que há, por parte da população em geral, uma séria falta de conhecimento da ação terapêutica das plantas medicinais da flora nativa do nosso próprio País que comumente são consumidas com pouca ou nenhuma comprovação de suas propriedades farmacológicas.

Varella (2010) aborda que nós, brasileiros, gostamos de pensar que tudo o que é natural é necessariamente benéfico, sem ao menos nos preocupamos em saber se há efeitos colaterais ou se as diversas plantas usadas na chamada "chapoeirada" combinam entre si. Esse autor, continuando seu raciocínio refere que a tradição de usar chás sempre existiu. Mas há uma diferença entre tomar chá de camomila para dormir melhor e usar chás para tratar de doenças graves.

Pelo exposto, o objetivo geral desse trabalho é identificar o nível de conhecimento sobre plantas medicinais e o uso de fototerápicos na comunidade escolar do meio rural de Cachoeira do Sul, onde está inserida a Escola Municipal de Ensino Fundamental (EMEF) Aldo Porto dos Santos, transformando essas informações numa ferramenta para introdução da Educação Ambiental. E como objetivos específicos definiram-se:

- $\quad$ Fazer um levantamento das plantas medicinais conhecidas na comunidade escolar pesquisada;

participantes;

Realizar atividades de pesquisa sobre plantas medicinais com os alunos

- Apresentar os principais usos das plantas medicinais em função da educação;

- Disponibilizar informações para o emprego correto das plantas medicinais, enfatizando os efeitos adversos e toxidez.

Acredita-se que essa sensibilização dos alunos em relação a importância da cultura que envolve as plantas medicinais, trazendo para o meio escolar a experiência de suas famílias, colabora não só para ampliar essa prática como também contribui na integração da escola com a comunidade. 
Em síntese, para atender ao proposto, este trabalho está estruturado em sete capítulos. Sendo que o primeiro capítulo trata da introdução na qual se expressa a preocupação com a Educação Ambiental nas escolas, o propósito do estudo sobre o conhecimento das plantas medicinais da comunidade escolar da EMEF Aldo Porto dos Santos e os objetivos específicos desse estudo.

O segundo capítulo apresenta os aspectos relacionados com a Educação Ambiental e com o Meio Ambiente apresentando seus conceitos e características. Enfatiza-se a importância de começar a prática da Educação Ambiental desde cedo, na infância. Firma-se também a necessidade da educação estar incorporada a cultura da comunidade escolar.

No terceiro capítulo conceitua-se plantas medicinais e se faz um breve relato sobre a história da humanidade e seu relacionamento com essas plantas. Também é mostrado alguns indicadores do amplo uso das plantas medicinais, faz-se a descrição de algumas plantas mais usadas na região sul do Estado e assinala-se determinadas recomendações na utilização das mesmas.

O quarto capítulo é destinado ao método de pesquisa, esclarecendo a proposta metodológica, o tipo de pesquisa utilizada, o local, a caracterização dos participantes, a forma como os dados foram coletados na primeira etapa e o desenvolvimento do projeto de pesquisa sobre plantas medicinais na segunda etapa.

No quinto capítulo estão descritas a apresentação e a análise dos resultados obtidos exibindo gráficos que evidenciam os resultados da pesquisa. Sendo que o mesmo está subdividido em seções, mostrando os resultados da primeira e segunda etapas do trabalho.

O sexto e último capítulo trata das considerações finais em que avaliou-se o resultado do trabalho em relação ao objetivos propostos e, como contribuição, considerou-se algumas sugestões para futuros trabalhos.

\section{REVISÃO BIBLIOGRÁFICA}

\subsection{Educação Ambiental e Meio Ambiente - conceitos e características}

Para abordar o assunto Educação Ambiental se faz necessário primeiramente definir o objeto pelo qual esta passou a existir, o Meio Ambiente. Segundo Neves (1992, p. 17): "meio ambiente é tudo o que tem a ver com a vida de um ser ou de um grupo de seres vivos. Tudo o que tem a ver com a vida, sua manutenção e reprodução". O autor acrescenta que nesta definição inclui-se os elementos físicos, o clima, os elementos vivos, os elementos culturais e a maneira como as atividades humanas interferem nestes elementos, e também as interações entre os elementos. Sendo assim, o meio ambiente não se trata apenas do meio natural, mas também se refere a tudo que é construído pelo homem.

Rebouças (2009), inspirado no conceito geral, considera meio ambiente como sinônimo de natureza, um local a ser respeitado, apreciado e preservado, porém não se pode prescindir que "meio ambiente", no sentido de ecossistema, é um conjunto de realidades ambientais considerando a diversidade do lugar e a sua complexidade. $\mathrm{O}$ autor prossegue considerando meio ambiente como um lugar onde se vive e que, consequentemente, se refere à vida cotidiana: casa, 
escola, e trabalho, mas quando a expressão "meio ambiente" se refere à biosfera, há uma interdependência das realidades sócio-ambientais em todo mundo, sendo a Terra a matriz de toda vida.

Corroborando com o exposto Scarlato (2009) afirma que a palavra ambiente possui um sentido clássico para a ecologia a qual é derivada da raiz grega oikos, que significa "casa". Para esse autor, ambiente além de ser o conjunto e interações entre os ecossistemas, abrange também a interação com a cultura humana, numa relação de reciprocidade, uma espécie de simbiose, tanto que qualquer mudança que venha a ocorrer em uma dessas duas partes afetará a outra.

Essas definições deixam claro de quanto depende-se do meio ambiente que, além de ser o gerador dos recursos necessários para nossa sobrevivência como: matéria-prima, energia, manutenção da vida etc. é também o modo pelo qual reencontra-se nossas origens e identidade biológica e cultural. Entretanto, segundo prossegue Scartlato (2009), à medida que o homem desenvolveu tecnologia e cultura, foi ao mesmo tempo retraindo, num processo gradual e progressivo, sua natureza instintiva, responsável pela sua sobrevivência e pela sobrevivência das outras espécies de animais em que a preservação do habitat é indispensável à vida.

Esta falta de comprometimento com a natureza já existe desde a colonização do Brasil, pois de acordo com Chiavenato (1989) José Bonifácio de Andrade e Silva, o "Patriarca da Independência", em 1823 já manifestava séria preocupação com a agressão sofrida pelo meio ambiente ao preparar uma representação à Assembléia Geral Constituinte com o seguinte trecho:

[...] nossas preciosas matas vão desaparecendo, vitimas do fogo e do machado destruidor, da ignorância e do egoísmo; nossos montes e encostas vão-se escalvando diariamente e, com o andar do tempo, faltarão as chuvas fecundantes, que favoreçam a vegetação, e alimentem nossas fontes e rios, sem o que o nosso belo Brasil, em menos de dois séculos, ficará reduzido aos paramos e desertos áridos da Líbia. Virá então esse dia (dia terrível e fatal), em que a ultrajada natureza se ache vingada de tantos erros e crimes cometidos (SILVA, 1823, apud CHIAVENATO, 1989 p.82).

Acompanhando o curso da história constata-se a gravidade da destruição ambiental prevista por José Bonifácio. Conforme descreve Dias (2004), uma das principais catástrofes ambiental, no século XX, aconteceu em 1952 em conseqüência da densa poluição de Londres que causou a morte de 1.600 pessoas. Esse desastre, prossegue o autor, suscitou nos Estados Unidos o surgimento do ambientalismo a partir de 1960.

Minc (2005) relata que a Primeira Conferência Mundial sobre o Meio Ambiente da Organização das Nações Unidas, em Estocolmo ocorreu em junho de 1972. Nessa Conferência foi pronunciado um alerta para as iminentes catástrofes, caso os países mais ricos do globo, aqueles pertencentes ao Clube de Roma, prosseguissem com o crescimento a qualquer preço. Essas declarações fazem perceber o quanto o homem está gradativamente destruindo seu habitat de modo que está comprometendo progressivamente a própria sobrevivência.

Portanto é imprescindível restabelecer a noção no ser humano de pertencimento ao meio ambiente, no qual possui vínculos naturais para a sua sobrevivência. Conforme lembra Dajoz (1973), ter a noção de que o homem, como qualquer outro ser vivo, é um elemento da biosfera tem importante conseqüência na preservação do meio ambiente, uma vez que na estreita interdependência que liga entre si os diversos constituintes de um ecossistema a proteção da natureza resulta na proteção do próprio homem. $O$ autor confirma esse pensamento usando a seguinte citação: 
De maneira geral, a biosfera caracteriza-se por grande estabilidade em face das influências exteriores, o que se reflete no fato de poder suportar, sem perturbar os processos essenciais, profundas modificações de sua estrutura... Esta plasticidade constitui um importante trunfo para o homem, porque lhe permite, em larga margem, transformar a biosfera e explorar alguns de seus elementos de acordo com as necessidades. Entretanto, a transformação não pode ultrapassar certos limites - que dependem do modo de intervenção e do tipo ecológico considerado - sem ameaçar o equilíbrio dinâmico da biosfera. Em vastas regiões do mundo estes limites já foram ultrapassados, o que teve como resultado a deterioração de uma considerável parte da biosfera, o esgotamento dos solos e dos recursos de água doce, fazendo desaparecer numerosas espécies vegetais e animais. O homem e a sociedade humana são parte integrante da biosfera e dependem estreitamente de seus recursos. A proteção da biosfera é de capital importância para a humanidade (UNESCO s/d, apud DAJOZ, 1973, p. 435).

Hoje, tem-se a consciência de que a exploração desequilibrada dos recursos naturais tanto os renováveis quanto os não renováveis tem causado danos consideráveis e até irreparáveis constituindo uma ameaça ao meio ambiente. Tais problemas, conforme narra Scarlato (2009) têm suscitado discussões que vêm congregando diversos setores da sociedade na construção de alternativas que visem buscar uma solução.

De acordo com os relatos de Souza (2000) a Educação Ambiental surgiu para atender às necessidades do momento, com o objetivo de corrigir danos concretos e urgentes que representam ameaça ao meio ambiente. No Brasil, segundo Carvalho (2004) esta temática aparece na legislação desde 1973, mas é nas décadas de 80 e 90, com o desenvolvimento constante da consciência a respeito do assunto que ela se torna conhecida sendo criado em 1984 o Programa de Educação Ambiental (PRONEA) e em 1988 foi incluída no capítulo do meio ambiente da Constituição. Em 1999 foi aprovada como lei e em 2001 o Ministério de Educação e Cultura (MEC) implementou o Programa Parâmetro em Ação: meio ambiente na escola, pondo em prática o que rege a lei de 27 de abril de 1999.

Respaldando o exposto, a Lei no. 9.795 de 1999 que institui a Política Nacional de Educação ambiental conceitua Educação Ambiental como sendo: "processos por meio dos quais o indivíduo e a coletividade constroem valores sociais, conhecimentos, habilidades, atitudes e competências voltadas para a conservação do meio ambiente, bem de uso comum do povo, essencial à sadia qualidade de vida e sua sustentabilidade" (art. 1ํ). A própria Lei no Art. 2o, diz que a Educação Ambiental deve ser uma ação educativa permanente ao afirmar: "A educação ambiental é um componente essencial e permanente, devendo estar presente, de forma articulada, em todos os níveis e modalidades do processo educativo, em caráter formal e não-formal" (DIAS, 2004, p. 202).

Novelli (2006) reitera afirmando que a Educação Ambiental se propõe a atingir todos os cidadãos por meio de um processo pedagógico participativo e permanente, o qual procura sensibilizar tanto o educando quanto a comunidade e para ser eficaz deve promover, concomitantemente, o desenvolvimento de conhecimento e de atitudes necessárias à preservação, à prevenção e à melhoria da qualidade de vida. De igual modo a UNESCO-PNUMA (1997) confirma que a Educação Ambiental é de fato um processo permanente no qual os indivíduos e a comunidade tomam consciência do seu meio ambiente e adquirem conhecimentos, habilidades, experiências, valores e a determinação que os tornam capazes de agir, individual ou coletivamente, na busca de soluções para os problemas ambientais. Seguindo esse raciocínio pode-se assegurar que: 
A educação ambiental é de uma importância tal que transcende o que muita gente pensa. Não se resume aos cuidados que se devam ter com as plantas e os animais, é muito mais que isso. O seu objetivo é transformar comportamentos que visam mostrar que é possível o desenvolvimento com um mínimo de agressão ao meio ambiente; mostrar que certos procedimentos melhoram a qualidade de vida e protegem a saúde a curto médio e longo prazo; prorrogar o tempo de utilização dos recursos naturais, dando chance para os que virão depois, também poderem se valer deles para as suas necessidades (PORTUGAL, 1998, s/p).

Pelo exposto até agora, há um consenso geral de que para a Educação Ambiental ser efetiva é necessário dois tipos de mudança: mudança da mente e mudança de comportamento. Nestes dois casos justifica-se o adágio popular que diz: "é de pequenino que se torce o pepino". Fazendo alusão a esse dito, Portugal (1997) garante que a educação é sempre mais efetiva se começada na infância, pois a mente humana enquanto está se formando é mais receptiva aos ensinamentos, por isso ser tão importante um bom livro didático e um professor comprometido. Boschilia (2003, p.336) também concorda que a Educação Ambiental deva começar desde cedo quando diz: "O respeito à natureza tem de ser adquirido nos primeiros anos de vida. Os pais, a escola, toda a sociedade tem de investir na criança, para que ela cresça consciente da importância de preservar o planeta".

\subsection{Educação Ambiental e a cultura local}

Quando se faz referência ao desenvolvimento de uma população e mudança de comportamento, consequentemente pensa-se em ação educativa. Mas segundo Carvalho (2004) a aprendizagem percorre caminhos distintos, sendo que o aprender faz parte de um contexto cultural no qual a ação humana tem a ver com a realidade de cada comunidade.

Todavia, o desenvolvimento de uma cultura de paz por meio de amplo acesso ao conhecimento, só poderá ser atingido mediante um processo educacional que valorize o individuo em sua totalidade. A valorização do individuo, por sua vez, implica o reconhecimento do outro, que não pode ser concebido a priori como objeto, o que seria uma forma de colonialismo. Em adição, acrescente-se que "como a solidariedade é uma forma de conhecimento que se obtém por via do reconhecimento do outro, o outro só pode ser reconhecido enquanto produtor de conhecimento", o que significa um profundo respeito aos saberes, a inteligência e a cultura do povo (WERTHEIN, 2000, p.7-8).

Brasil (1997, p. 3) expressa no seu art. 1ㅇ que: "A educação abrange os processos formativos que se desenvolvem na vida familiar, na convivência humana, no trabalho, nas instituições de ensino e pesquisa, nos movimentos sociais e organizações da sociedade civil e nas manifestações culturais". Essas manifestações culturais subentendem-se que são aquelas características que são transmitidas de geração em geração, pois segundo Morin (2001) são os saberes, os fazeres, as regras, as normas, as proibições, as estratégias, as crenças, as idéias, os valores e os mitos, que são reproduzidas em cada individuo, controlando a existência da sociedade. Esse autor ainda assegura que cada cultura é única, que não existe sociedade humana, antiga ou moderna, desprovida de cultura e que o fenômeno da unidade e da diversidade das culturas é de extrema importância, pois é a cultura que mantém a identidade humana naquilo que 
têm de específico como as identidades sociais. A incorporação de uma cultura a outra é enriquecedora, já que há uma integração das características próprias de cada uma.

Então, conforme pergunta Freire (2007, p. 30): [...] "por que não estabelecer uma "intimidade" entre os saberes curriculares fundamentais aos alunos e a experiência social que eles têm como indivíduos?". É com o intuito de responder a esse questionamento que a escola deve enfrentar o desafio de construir novos saberes, preservando a cultura que caracteriza a comunidade em que a escola está inserida sem romper com o sincretismo inicial da vida humana, pois como o próprio Freire $(2005$, p. 79$)$ enfatiza: "desta maneira, o educador já não é o que apenas educa, mas o que, enquanto educa, é educado, em diálogo com o educando que, ao ser educado, também educa". Mas para que se possa entender o mundo primeiramente tem-se que compreender o relacionamento do homem com o seu ambiente, é o que confirma Werthein (2000, p.17) quando declara: "a compreensão do mundo passa necessariamente pela compreensão do outro e das relações que ligam o ser humano ao seu meio ambiente".

Para que essa percepção ocorra, na reflexão de Zieger (2004) a cultura regional precisa ser estimulada e valorizada nos currículos escolares. Essa autora comenta que: "os saberes populares são parte importante desse processo, e os seus ditos constituem-se em riqueza de verdades" (p.54). Neste sentido coloca-se a cultura como sendo uma peça mestra desse processo, conforme justifica os PCNS (1996 apud SILVEIRA, 2005, p.11): "respeitar as diferenças e não convertê-las em desigualdades deve ser o propósito da escola. As diferenças não estabelecem obstáculos para o cumprimento da ação educativa; podem e devem ser fator de enriquecimento".

Lautert et al. (2006) assegura que atualmente a Educação Ambiental representa uma ferramenta cuja propriedade é de contribuir na formação de cidadãos críticos, participativos e responsáveis que buscam cultivar atitudes e formas preventivas. Mas essa mudança de comportamento, segundo o autor, é um processo longo e contínuo de aprendizagem, com uma filosofia de trabalho voltada ao exercício pleno da cidadania. O autor ainda afirma que a Educação Ambiental deve ter como espaço de aprendizagem os sistemas educacionais formais, através da incorporação da importância ambiental no espaço compreendido dentro dos limites curriculares e das atividades extracurriculares das instituições de ensino.

Segundo Lautert et al. (2006) as ações e práticas educativas voltadas à sensibilização, organização e participação da coletividade, devem envolver e obter o comprometimento não só da escola, mas também da família e da comunidade em geral. Segundo o mesmo autor, para que um programa de Educação Ambiental seja efetivo deve promover, simultaneamente, o desenvolvimento do conhecimento, de atitudes e de habilidades necessárias à preservação, a prevenção e à melhoria da qualidade de vida.

Neste contexto, as plantas medicinais se ajustam como um instrumento importante tanto para o aprendizado na Educação Ambiental como para a valorização da cultura local, pois segundo Simões et al. (1988), a utilização de plantas medicinais é o resultado do acumulo de conhecimentos antigos sobre a ação dos vegetais pelos mais diversos grupos culturais. Partindo-se dessas declarações deduz-se que é dever da escola converter as diferenças em instrumento de construção da cidadania, valorizando a cultura de sua própria comunidade e, ao mesmo tempo, buscando ultrapassar seus limites incorporando o conhecimento de outras culturas.

Complementando a idéia da importância em oferecer ao aluno situações que possibilitem o desenvolvimento da capacidade criativa Zieger (2004) afirma que é na escola que a pessoa precisa aprender pesquisando e estabelecendo conexões, refletindo sobre o meio em que vive. Sendo assim, pode-se reconhecer um momento favorável para o estudo sobre as plantas medicinais o 
qual apresenta-se como um instrumento de uso relevante no processo de ensino-aprendizagem, promovendo o conhecimento da história e dos fatos a elas ligados, pois conforme foi relatado, a preocupação gira em torno da conservação do meio ambiente, da educação e do intercambio do conhecimento entre culturas diferentes. Por conseguinte, o estudo das plantas medicinais possibilita a pesquisa e a iniciação científica e ao mesmo tempo possibilita desenvolver atitudes de preservação ambiental e, também melhoria da qualidade de vida.

\section{3 Plantas Medicinais e a História da Humanidade}

Antes da exposição de um pouco da história humana e seu relacionamento com as plantas medicinais é preciso definir quando e porque uma planta é denominada medicinal. Fernandes $(2003$, p. 6) estabelece de forma direta que: "são plantas que através dos seus princípios ativos têm a capacidade de prevenir doenças e / ou curar a saúde". Lorenzi (2008) discorre que o emprego das plantas medicinais para a recuperação da saúde se dá pelo fato delas apresentarem propriedades de provocar reações benéficas no organismo no que se chama de princípio ativo, podendo ser constituído de uma única substância existente na planta ou de um conjunto que atua de forma sinergética. Wermann et al. (2009, p. 13) conceitua que: "planta medicinal é aquela que, administrada de qualquer forma, exerce ação farmacológica em seres humanos, animais e plantas. É aquela que contém princípios ativos responsáveis pelas reações terapêuticas no organismo".

De outra maneira Schipper (1999) esclarece que as substâncias medicinais provêm das reservas de aminoácidos e ácidos graxos presentes nas células da planta viva. Um imenso grupo desses compostos é o dos glicosídeos que tem como exemplo a salicilina, presente na casca de alguns choupos e salgueiros e foi da salicilina que os químicos sintetizaram o ácido acetil salicílico, princípio ativo da aspirina.

O emprego das plantas medicinais na recuperação da saúde, segundo Lorenzi (2008) remonta à pré-história e está associado a lendas, mágicas e rituais. O autor conta que os colonizadores europeus incorporaram em seus hábitos o uso do tabaco, um costume praticado por populações indígenas americanas, pois devido a seus efeitos narcóticos, possuía a capacidade de colocá-los em contato com os seus deuses. Balbach (199-), afirma que os antigos egípcios, civilização reconhecida por desenvolver a técnica de embalsamar os cadáveres, descobriram o poder curativo das plantas por meio de experimentos e muitas vezes eram escolhidas pelo cheiro, pois acreditavam que certos aromas afastavam os maus espíritos. Mas além das plantas aromáticas, eles também faziam uso de plantas como a papoula (sonífera), a cila (cardíaca), a babosa e o óleo de rícino (catárticos), cujos efeitos eles bem conheciam.

Dando continuidade a história da utilização de plantas medicinais Balbach (199-) descreve que entre 460 - 361 a.C. na Grécia, Hipócrates, considerado o pai da medicina, também empregava centenas de drogas de origem vegetal. A autora ainda conta que os árabes utilizaram o conhecimento da ciência fitoterápica dos gregos, romanos e outros povos, sendo Abd-Allah Ibn Al-Baitar o maior especialista árabe no campo da botânica aplicada à medicina, buscando conhecimento em muitos países para produzir uma obra muito valiosa na qual descreveu mais de 800 tipos de plantas.

Segundo Schipper (1999), Hernán Cortes juntamente com os conquistadores, em 1519, ao invadirem o México encontraram uma cultura rica em conhecimentos sobre a flora local. $\mathrm{O}$ autor 
conta que os imperadores astecas estimulavam o estudo de todos os aspectos do vegetal, também eram enviados jardineiros a todos os cantos dos domínios astecas para colher plantas raras e valiosas. Das plantas existentes nos jardins dos imperadores, os médicos faziam experiências, enquanto os jardineiros testavam as novas variedades.

Já no Brasil, conforme relata Simões et al. (1988), além do conhecimento dos nossos nativos, igualmente tivemos a contribuição trazida pelos escravos e imigrantes, a qual teve importância relevante para o surgimento de um conhecimento rico e original de plantas medicinais.

\begin{abstract}
Do conhecimento indígena sobre as plantas medicinais sobrevive na forma das "garrafadas", de ampla difusão nos meios rurais, e que apresentam evidentes elementos do sincretismo cultural brasileiro. Uma garrafada é composta de uma combinação de partes escolhidas de plantas medicinais (ramos, folhas, raízes e cascas de arvores), que são colocadas secas ou frescas entro de garrafas com aguardente, vinho branco ou, mais raramente, água. Em seguida elas são enterradas por alguns dias e depois entregues aos pacientes. As plantas escolhidas para a garrafada, o tempo que ficam enterradas e o ritual das orações variam de acordo com as enfermidades. Apesar de seu uso ser bastante disseminado entre as populações de baixa renda, a comprovação da eficácia de tais preparos ainda carece de pesquisas mais minuciosas (SCHIPPER, 1999 p. 23 - 24).
\end{abstract}

Pelo exposto percebe-se que as lendas estão interligadas à história das plantas medicinais. Segundo Fernandes (2005) os indianos possuem a mais antiga prática com ervas, existente há mais de 5000 anos. $O$ autor conta que na mitologia hindu, quando o homem surgiu na Terra, o deus Indra previu que os atos humanos poderiam gerar males físicos e doenças. Esse deus pediu, então, a Brahma, o Senhor absoluto, que insuflasse nas plantas o poder de curar e assim foi feito. A partir desse pedido, todas as ervas, até então, semelhantes entre si, ganharam uma enorme diversidade de formas, aromas e virtudes terapêuticas.

Não é de admirar que o homem tenha atribuído poderes mágicos às plantas, pois de acordo com Schipper (1999), na luta para controlar as forças da natureza, os humanos buscaram auxílio nas plantas para o alimento, o abrigo, a roupa, as armas e até a cura. Pelo motivo das plantas oferecerem tanto e manterem uma relação íntima com o cotidiano das pessoas é que lhes é atribuído diversos mitos, diz Schipper. Essa mesma magia também é revelada nas histórias da Bíblia, pois em Êxodo 3:2 é demonstrado o papel relevante das plantas na vida dos homens e mulheres daquela época quando relata: "apareceu-Ihe o Anjo do Senhor numa chama de fogo, no meio duma sarça; Moisés olhou, e eis que a sarça ardia no fogo e não se consumia" (BíBLIA, 1993, p. 58).

Em Gênesis no capítulo 30 e versículo 14, também está descrita a história de Lia e Raquel, as quais desejavam dar filhos a Jacó. Ambas fizeram uso do chá da raiz de mandrágora para estimular a concepção: "foi Ruben nos dias da ceifa do trigo, e achou mandrágoras no campo, e trouxe-as a Lia, sua mãe. Então, disse Raquel a Lia: - Dá-me das mandrágoras de teu filho" (BÍBLIA, 1993, p. 32).

Mas o mito ignora o fato de que muitos remédios produzidos diretamente do preparo de plantas funcionavam realmente. Schipper (1999, p. 10) descreve: "o alho é uma planta que há muito desfruta da fama de instrumento de magia branca - teria o poder de repelir as forças malignas da magia negra. Se a magia está na capacidade de impedir a má nutrição, o alho é sem duvida mágico". Esse autor ainda comenta que quando acometidos pela dor ou por alguma doença, os povos antigos tinham pouca escolha além de recorrer às plantas. Criados pelo método 
de experiência e erro, muitos tratamentos fitoterápicos tinham uma eficácia admirável, mas depois a medicina tornou-se teórica, e esse saber caiu em desgraça, qualificado como superstição. A mudança só se deu quando a medicina abriu suas portas. Agora, a ciência está reafirmando muito do antigo saber, e ampliando os horizontes da fitoterapia.

Durante a maior parte da existência humana, as plantas eram praticamente tudo de que dispunham os curandeiros e os que esperavam ser curados. Isso ainda é verdade em grande parte dos paises pouco desenvolvidos. Só no século XX os avanços na química, na tecnologia e na farmacologia tornaram possível a síntese de muitos dos compostos hoje usados na medicina (SCHIPPER, 1999, p.29).

De acordo com Schiper (1999) percebe-se que no mundo se conhecem inúmeras plantas com amplo valor para a farmacopéia moderna proveniente da ciência de civilizações do passado ocorrendo o fato de que muitos remédios que comprados na farmácia contêm os mesmos ingredientes ativos que as plantas medicinais empregadas por culturas pré-científicas. Por exemplo: "o chá feito de um arbusto que os chineses chamam de mahuang, Ephedra sinica, alivia tosses, resfriados e asma. É a fonte da efedrina, usada em muitos remédios, incluindo os descongestionantes" (p.28).

Hoje, conforme defende Franco (2004), graças ao desenvolvimento científico, têm-se maiores condições de comprovarem-se os conhecimentos experimentais milenares do uso das plantas. Comparando a riqueza de espécies vegetais da Amazônia com o resto do mundo, o autor informa que na Alemanha a fitoterapia participa com mais de $30 \%$ na produção de remédios ao passo que no Brasil seria de apenas $5 \%$, calcula-se que nos países industrializados metade dos medicamentos apresentam na sua fórmula princípios ativos extraídos de planta e que cientistas que fazem pesquisa metodológica a partir das plantas já consagradas pelo uso popular se surpreendem com o número de acertos e resultados bem sucedidos.

A medicina natural com toda sua tradição milenar é também agora um novo conceito de mercado. A necessidade exige e a ciência busca a unificação do progresso com aquilo que a natureza oferece, respeitando a cultura do povo em torno do uso de produtos ou ervas medicinais para curar os males. Nos dias atuais, cientistas pesquisam as plantas com poder de curar à luz da fitoterapia que confirma cientificamente os conhecimentos populares sobre estas plantas (ACCORSI, 2000, p.5).

Como foi apresentado, o uso das plantas medicinais vem desde os primórdios da civilização, abrangendo conhecimentos adquiridos através dos tempos e que foram transmitidos de geração em geração, acumulando informações que, por vezes confundiu-se com a crença das pessoas, mas que serviu como fonte de pesquisa para muitos cientistas ao longo da história da humanidade. Por outro lado um fato muito importante deve ser levado em conta: o uso correto das plantas medicinais.

\subsubsection{A utilização de plantas na medicina popular}

Pelo divulgado nos estudos parece correto julgar que cada cultura faz uso de plantas como um recurso medicinal, sendo uma prática generalizada na medicina popular. Mas segundo Simões et al. (1988), esta prática não se limita mais apenas às zonas rurais ou regiões carentes de assistência médica ou de farmácias, presume-se, atualmente, que as drogas vegetais são muito 
empregadas no meio urbano, não só como uma forma alternativa de medicina, mas também como complementação de tratamentos oficiais.

Nos últimos anos, alguns fatores têm contribuído para o aumento da utilização de tal recurso, mesmo em camadas sociais que até então não o empregavam: a crise econômica, o alto custo dos medicamentos industrializados, o difícil acesso da população à assistência médica e farmacêutica, bem como uma tendência generalizada dos consumidores em utilizar, preferencialmente, produtos de origem natural (SIMÕES et al., p. 9).

Para Simões et al. (1998) há outros indicadores do amplo uso de plantas medicinais como: a proliferação de laboratórios fitoterápicos e o comércio intenso destes produtos nos mais diversos seguimentos do mercado. $O$ uso de plantas medicinais pela população mundial tem sido muito expressivo na atualidade. Registros da Organização Mundial de Saúde (OMS) mostram que cerca de $80 \%$ da população mundial fez uso de algum tipo de erva na busca de alívio de algum sintoma doloroso ou desagradável.

A mesma autora admite que a prática no uso de plantas terapêuticas vem sendo incentivada pela propaganda nos diferentes meios de comunicação, através da divulgação de características "milagrosas" de determinadas plantas, geralmente sem um pré-julgamento, ignorando ou omitindo as contra-indicações, as precauções e os efeitos desejados ou não destas plantas. Tal realidade é confirmada por Simões et al. (1988, p. 9), quando afirma: "o uso pouco cuidadoso de plantas medicinais fora de seu contexto original e sem respaldo acadêmico, tem dado origem a intoxicações atribuíveis aos efeitos já conhecidos da planta ou ainda ao uso de planta errada por confusão na identificação das espécies".

É por essas razões que trabalhos de divulgação e resgate do conhecimento de plantas se faz imprescindível, principalmente nas regiões mais carentes.

\footnotetext{
O emprego correto de plantas para fins terapêuticos pela população em geral, requer o uso de plantas medicinais selecionadas por sua eficácia e segurança terapêuticas, baseadas na tradição popular ou cientificamente validadas como medicinais. No caso de programas de fitoterapia em saúde pública, é fundamental que as espécies usadas sejam cientificamente validadas e, ainda, a escolha das formas corretas de preparação e administração de seus produtos sejam destinados para uso ambulatorial, hospitalar ou caseiro (LORENZI, 2008, p.14).
}

Situação que também oferece risco à saúde, alerta Lorenzi (2008), é a utilização indiscriminada e prolongada de certas plantas medicinais que apresentam propriedades tóxicas como: alcalóides pirrolizidínicos, considerados cancerígenos e hepatotóxicos, estão presentes no "fedegoso" (Heliotropium indicum L) e no "confrei" (Symphytum officiunalis); alcalóides tropânicos que causam confusão mental; glicosídeos cianogênicos, causa distúrbio no sistema nervoso central, alteração degenerativa do nervo óptico e um estado de hipoxemia que, no caso de ingestão da "mandioca" (Manihot esculenta Kranz), algumas vezes é seguida da perda de consciencia e morte; glicosideos antraquinônicos e suas agliconas, esses compostos podem causar severa intoxicação renal, ocorre comumente na "babosa" (Aloe ssp.).

A mesma autora comenta que embora estas substâncias não desqualifiquem as propriedades medicinais da planta é importante informar-se quanto ao efeito, se é cumulativo ou se a planta é imprópria para o uso interno. Além disso, todas as plantas têm mais de um princípio ativo e algum pode ser contra indicado para o usuário. Outra conseqüência desastrosa, alerta Simões et al. (1988) tem sido a exploração predatória de algumas plantas "milagrosas" em moda 
colocando-as na lista de plantas ameaçadas de extinção, como é o caso da cancorosa-de-trêspontas (Jodina rhombifolia Hook. Et. Arn.) e do ipê roxo (Tabebuia avellanedae Lorentz ex. Grisebach).

Ciente da carência de qualificar o uso das plantas medicinais Wermann (2009) descreve um trabalho inovador desenvolvido pela mesma e a equipe de extensionistas rurais da EMATER/RSASCAR, o projeto Horto Medicinal: relógio do corpo humano. Segundo essa autora o projeto surgiu dado à importância de conhecer as plantas medicinais e também por sua função didática uma vez que estimula o respeito ao meio ambiente, o convívio harmônico com as plantas e o auto conhecimento do corpo humano. Nesse projeto a autora salienta um fator inédito que o caracteriza; a relação das plantas medicinais com os principais órgãos do corpo humano, informando os horários de maior atividade de cada órgão e quais as plantas recomendadas para auxiliar o bom funcionamento do mesmo.

A energia vital percorre todo o circuito dentro de um rítmo, horário que se inicia das 3 às 5 horas da manhã no meridiano do pulmão, e obedecendo ao seguinte percurso: das $5 \mathrm{~h}$ às $7 \mathrm{~h} /$ intestino grosso; das $7 \mathrm{~h}$ às $9 \mathrm{~h} /$ estômago; das $9 \mathrm{~h}$ às $11 \mathrm{~h} /$ baço-pâncreas; das $11 \mathrm{~h}$ às $19 \mathrm{~h} /$ rins; das $19 \mathrm{~h}$ às $21 \mathrm{~h} /$ circulação-sexo; das $21 \mathrm{~h}$ às $23 \mathrm{~h} /$ triplo aquecedor envolvendo três sistemas do corpo: (sistema digestivo / respiratório / excretor); das $23 \mathrm{~h}$ à $1 \mathrm{~h}$ / vesícula biliar; da $1 \mathrm{~h}$ às $3 \mathrm{~h} /$ fígado (WERMANN et al., 2009, p. 14).

Definindo essa característica como fundamento do projeto Wermann et al. (2009) esclarece que a mesma está baseado na medicina tradicional chinesa conforme ilustrado na Figura 1.

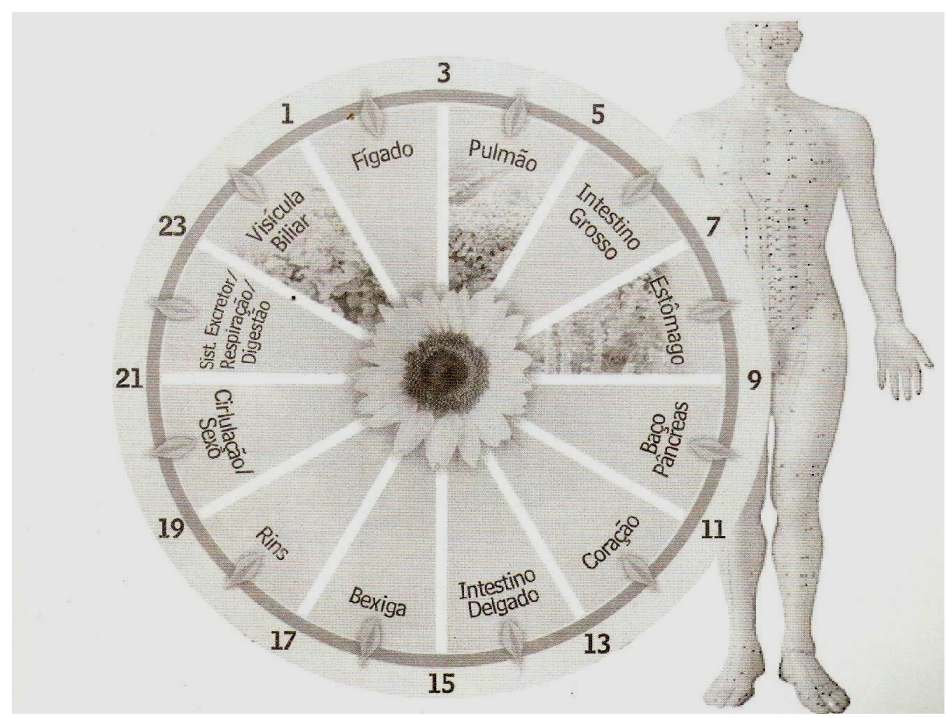

Figura 1 - O Relógio do corpo humano

A mesma autora ainda declara que de acordo com a medicina chinesa, se quiséssemos tratar um doente com sucesso, seria preciso fazê-lo nas horas propicias, procurando observar a manifestação de depuração deste órgão no momento que estiver no seu pico energético.

Apoiando-se nesta teoria e aproveitando a idéia do projeto elaborado pela EMATER/RSASCAR (2009), é que surgiu o propósito de reproduzir, de maneira simplificada, a obra do "relógio do corpo humano" na Escola Municipal de Ensino Fundamental Aldo Porto dos Santos do 
município de Cachoeira do Sul - RS, denominado "O relógio das plantas medicinais". A construção da obra faz parte da segunda etapa do projeto de estudo sobre a utilização do conhecimento de plantas medicinais como ferramenta para estimular a preservação ambiental na referida escola.

\subsubsection{Formas de emprego de plantas medicinais e recomendações para utilização.}

Para usufruir de modo pleno da capacidade medicinal das plantas, devem ser seguidos alguns cuidados básicos conforme descreve Lorenzi (2008, p. 18):

As plantas medicinais podem ser usadas, conforme o caso, em preparações diversas para serem ingeridas, ditas de uso interno (chá, infuso, cozimentos ou decoctos, maceração etc.) e em outras preparações para uso na pele ou nas mucosas das cavidades naturais, ditas de uso externo. [...] O primeiro cuidado geral é a limpeza, especialmente no caso das preparações caseiras e nas pequenas oficinas farmacêuticas, tudo, papeiros, colheres, copos, xícaras e coadores deverão estar limpos como se fossem novos.

Fernandes (2005 p. 9) apresenta as duas formas de utilização das plantas medicinais: uso interno e uso externo. Para o uso interno, esse autor apresenta que as ervas medicinais devem ser preparadas na forma de chá, que consiste em extrair os seus princípios ativos, usando, como veículo, a água quente. $O$ autor recomenda que as ervas devem ser bem fragmentadas para maior contato com a água e podem ser preparadas a partir de dois processos: infusão e deccocão, apresentados no Quadro 1.

\begin{tabular}{|l|l|}
\hline Processo & Detalhamento \\
\hline 1 - Infusão & $\begin{array}{l}\text { A substância é colocada numa vasilha, que depois recebe água fervente e é tampada. Após } \\
\text { descansar por certo tempo, côa-se a mistura. O tempo de infusão varia de } 10 \text { a } 15 \text { minutos para } \\
\text { folhas e flores e várias horas no caso de raízes. O processo é praticamente indicado para as } \\
\text { plantas aromáticas. }\end{array}$ \\
\hline $\begin{array}{l}2 \text { - Decocção ou } \\
\text { cozimento }\end{array}$ & $\begin{array}{l}\text { Coloca-se a erva em um recipiente com tampa, adiciona-se água fria, ferve-se de } 10 \text { a } \\
20 \text { minutos, deixa-se repousar por mais } 10 \text { minutos e filtra-se. } \\
\text { Obs.: Os chás para resfriados e bronquites devem ser tomados bem quentes. } \\
\text { Os chás para problemas digestivos e diarréias devem ser tomados frios ou gelados. } \\
\text { Os chás devem ser consumidos de imediato ou, no máximo, em 24 horas. }\end{array}$ \\
\hline
\end{tabular}

Quadro 1-Formas de utilização das plantas medicinais para uso interno.

Fonte: Fernandes (2005).

Já para o uso externo, no qual se preparam pomadas, ungüentos ou cataplasmas, Fernandes (2005) adverte que é importante utilizar somente as ervas próprias para essa finalidade. Para o uso externo são utilizados três processos: maceração, contusão e tintura, conforme descritos no Quadro 2. 


\begin{tabular}{|l|l|}
\hline Processo & Detalhamento \\
\hline 1-Maceração & $\begin{array}{l}\text { Para a preparação de pomadas, ungüentos ou cataplasmas é importante observar, primeiro, quais } \\
\text { são as ervas mais adequadas para esse fim, sendo que, no preparo, são usados os seguintes } \\
\text { processos: } \\
\text { Neste processo, a substância vegetal é deixada em contato com o líquido usado para dissolver o } \\
\text { princípio ativo (água, álcool, vinho ou vinagre) em temperatura ambiente. } \\
\text { Para folhas e sementes, a maceração deverá ser de } 10 \text { a } 12 \text { horas; para rizomas, cascas e raízes, de } \\
1618 \text { horas; para lenho, cascas e raízes duras, de 22 a 24 horas. Deve-se agitar o preparado a cada } \\
6 \text { horas, filtrar e consumi-lo em } 24 \text { horas. }\end{array}$ \\
\hline 2-Contusões & $\begin{array}{l}\text { A substância é colocada em gral (pote de louça ou vidro de boca larga) e socada até o ponto } \\
\text { desejado (pó ou pasta). Serve para a produção de pomadas ou cataplasmas. }\end{array}$ \\
\hline 3-Tintura & $\begin{array}{l}\text { Consiste no uso do álcool ou do éter, que impregnam o princípio ativo de uma ou mais } \\
\text { substâncias. Este processo pode ser usado para uso interno ou externo. Para o uso interno, a } \\
\text { preparação requer um conhecimento mais aprofundado, minucioso e delicado. Já, para uso } \\
\text { externo, o processo é mais fácil: reúne as ervas de que precisa, coloca-as em um recipiente com } \\
\text { álcool, deixa por cinco dias em local fechado sem presença de luz (este tipo de tintura é muito } \\
\text { usado como fomentação). }\end{array}$ \\
\hline
\end{tabular}

Quadro 2 - Formas de utilização das plantas medicinais para uso externo.

Fonte: Fernandes (2005).

\subsubsection{Orientações importantes.}

De forma a usufruir completamente das propriedades terapêuticas das plantas medicinais, é importante seguir alguns passos básicos, conforme recomendam os autores Simões et al. (1988), Fernandes (2005), Lorenzi (2008) e EMATER (2008) no Quadro 3.

\begin{tabular}{|c|c|}
\hline Autores & Precauções \\
\hline $\begin{array}{l}\text { Simões et al. } \\
\text { (1988) }\end{array}$ & $\begin{array}{l}\text { - Nunca coletar plantas medicinais junto a locais poluídos. } \\
\text { - Não utilizar plantas medicinais durante a gravidez, a não ser sob orientação médica. } \\
\text { - Evitar utilizar chás laxantes e/ou diuréticos. } \\
\text { - Certas plantas medicinais são recomendadas para uso externo e não devem ser ingeridas sob forma } \\
\text { de chás. } \\
\text { - Não se deve esperar curas milagrosas utilizando plantas medicinais em doenças graves, isto poderá } \\
\text { retardar o início de uma terapia eficaz e agravar a doença. }\end{array}$ \\
\hline $\begin{array}{l}\text { Fernandes } \\
(2005)\end{array}$ & $\begin{array}{l}\text { - Não se devem misturar muitas ervas, seja na produção de chás ou compostos de tinturas. No caso } \\
\text { de chás, é importante usar um a cada dia e repetir o uso após sete dias (evitando o uso de um único } \\
\text { princípio ativo pelo organismo). } \\
\text { - Os chás devem ser tomados sem nenhum tipo de adoçante, pois qualquer adoçante, em especial, o } \\
\text { açúcar branco, interfere na ação da planta. } \\
\text { - Para extrair das ervas medicinais o princípio ativo, é necessário o uso de utensílios adequados para } \\
\text { essa finalidade, como recipientes de louça, inox ou vidro, sendo que todos os utensílios usados na } \\
\text { preparação de chás e tinturas devem ser lavados com água quente ou esterilizados. } \\
\text { - É importante ter sempre uma bibliografia ou consultar alguma pessoa que tenha conhecimento e } \\
\text { que possa dar informações e instruções sobre o uso adequado das ervas medicinais. }\end{array}$ \\
\hline Lorenzi (2008) & $\begin{array}{l}\text {-Lembrar-se que plantas medicinais só podem ser consideradas medicamento quando usadas } \\
\text { corretamente, e que seu uso incorreto pode ser perigoso. } \\
\text { - Usar preferencialmene a planta fresca para a preparação de chas, cozimentos ou outras formas de } \\
\text { uso. } \\
\text { - Plantas secas somente devem ser utilizadas quando for possível adiquirí-las de fonte especializada e } \\
\text { segura. }\end{array}$ \\
\hline
\end{tabular}




\begin{tabular}{|l|l|}
\hline & $\begin{array}{l}\text { - Nunca utilizar uma planta medicinal seca que apresente sinais de preparação mal feita, ou que } \\
\text { esteja mofada ou apresente aspecto diferente do normal. }\end{array}$ \\
\hline $\begin{array}{l}\text { EMATER } \\
(2008)\end{array}$ & $\begin{array}{l}\text { - Somente devem ser utilizadas plantas que foram identificadas com segurança } \\
\text { - colher em dias secos, logo após a evaporação do orvalho; somente plantas bem desenvolvidas e } \\
\text { sadias. } \\
\text { - O local para secagem das plantas deve ser seco, limpo, arejado e à sombra. } \\
\text { - Usar recipientes de louça, inox ou vidro, para o preparo do chá. Após o preparo o chá deve ser } \\
\text { consumido por, no máximo, } 24 \text { horas, pois ocorrem reações químicas que podem transformar os } \\
\text { princípios ativos em outras substâncias prejudiciais à saúde. }\end{array}$ \\
\hline
\end{tabular}

Quadro 3 - Orientações importantes no uso das plantas medicinais.

Fontes: Simões et al. (1988), Fernandes (2005), Lorenzi (2008) e EMATER (2008).

Conforme o que foi descrito neste capítulo percebe-se que o uso das plantas medicinais embora sendo um conhecimento milenar também pode ser considerado uma prática atual, pois parece ter-se intensificado nos últimos anos até em camadas sociais que antes não o empregava. Graças ao desenvolvimento científico, hoje se têm maiores condições de comprovarem-se os conhecimentos experimentais milenares no uso dessas plantas. Mesmo assim, para que se possa desfrutar das potencialidades terapêuticas oferecidas pelas plantas medicinais não se pode negligenciar o devido conhecimento das mesmas conforme foi apresentado aqui.

\section{METODOLOGIA}

O estudo foi do tipo quanti-qualitativo e descritivo, sendo também realizado um estudo bibliográfico com o objetivo de encontrar conceitos e opiniões de diversos autores. Tendo como objeto de estudo de caso a comunidade escolar da EMEF Aldo porto dos Santos, localizada na região do Bosque, interior do município de Cachoeira do Sul, a proposta metodológica do trabalho consistiu na utilização da pesquisa do tipo exploratória direcionada a participantes específicos de acordo com a finalidade de cada objetivo, conforme demonstra o Quadro 4.

\begin{tabular}{|l|l|l|}
\hline Objetivos & Participantes & Coleta de dados \\
\hline $\begin{array}{l}\text { Identificar o nível de conhecimento sobre plantas medicinais na } \\
\text { comunidade escolar da EMEF Aldo Porto dos Santos. }\end{array}$ & $\begin{array}{l}\text { Pais de alunos e } \\
\text { professores da Escola }\end{array}$ & Questionário \\
\hline $\begin{array}{l}\text { Fazer um levantamento das plantas medicinais conhecidas na } \\
\text { comunidade escolar pesquisada. }\end{array}$ & $\begin{array}{l}\text { Pais de alunos e } \\
\text { professores da Escola }\end{array}$ & Questionário \\
\hline $\begin{array}{l}\text { Realizar atividades de pesquisa sobre plantas medicinais com os } \\
\text { alunos participantes. }\end{array}$ & Alunos do 6 o ano & Pesquisa bibliográfica \\
\hline $\begin{array}{l}\text { Apresentar os principais usos das plantas medicinais em função da } \\
\text { educação. }\end{array}$ & Alunos do 6 o ano & Pesquisa bibliográfica \\
\hline $\begin{array}{l}\text { Disponibilizar informações para o emprego correto das plantas } \\
\text { medicinais, enfatizando os efeitos adversos e toxidez. }\end{array}$ & Escola e comunidade & Pesquisa bibliográfica \\
\hline
\end{tabular}

Quadro 4 - Correlação entre objetivos, participantes e forma de coleta dos dados.

Para realizar a primeira etapa do trabalho foi desenvolvida uma pesquisa quantitativa na qual utilizou-se, como instrumento de coleta de dados, questionários contendo 8 perguntas, sendo 6 perguntas fechadas e 2 abertas. A primeira pergunta indagava sobre plantas medicinais que a comunidade mais usava, a segunda pergunta inquiria sobre o motivo pelo qual a pessoa 
usava essas plantas e na terceira interrogava sobre a maneira como aprendeu-se a utilizá-las. Na quarta pergunta a intenção foi saber se percebeu-se resultado no tratamento com plantas medicinais. A quinta pergunta questionou se o uso das plantas era motivado pelo baixo custo ou por não oferecer riscos, na questão seis se quis informar-se de que maneira as plantas medicinais são adquiridas.

A penúltima pergunta do questionário busca saber a opinião das pessoas quanto à incidência do uso das mesmas atualmente e a oitava e última questão procura saber da comunidade da importância de se cultivar uma horta com plantas medicinais na escola local.

As perguntas foram respondidas por cento e onze pessoas, em que noventa eram alunos, dezenove eram professores, uma era servente e uma merendeira. Os alunos, de maneira particular, após receberem orientações, levaram os questionários para que fossem respondidos pelos pais ou seus responsáveis. Após o recolhimento dos questionários, as respostas foram analisadas e o resultado de cada pergunta foi representado em forma de gráfico.

Na segunda etapa do projeto foi elaborado o "relógio das plantas medicinais" que contou com a participação da turma do 60 ano constituída por vinte alunos. Esta iniciativa teve como estímulo um projeto desenvolvido pela EMATER-RS/ASCAR conforme demonstrado no Quadro 5.

\begin{tabular}{|c|c|c|c|}
\hline Horário & Órgão & Ação principal & Planta medicinal \\
\hline $01 \mathrm{~h}$ às $03 \mathrm{~h}$ & Fígado & $\begin{array}{l}\text { Produzir a bile. Eliminar substâncias } \\
\text { nocivas. }\end{array}$ & $\begin{array}{l}\text { Alcachofra } \\
\text { Cardo Mariano }\end{array}$ \\
\hline $03 \mathrm{~h}$ às $05 \mathrm{~h}$ & Pulmão & $\begin{array}{l}\text { Fornecer oxigênio aos órgãos através } \\
\text { do sangue. }\end{array}$ & $\begin{array}{l}\text { Pulmonária } \\
\text { Violeta de Jardim }\end{array}$ \\
\hline $05 \mathrm{~h}$ às $07 \mathrm{~h}$ & Intestino Grosso & $\begin{array}{l}\text { Reter a sobra dos alimentos que } \\
\text { junto com a água formam as fezes. }\end{array}$ & $\begin{array}{l}\text { Linhaça } \\
\text { Tansagem }\end{array}$ \\
\hline $07 \mathrm{~h}$ às $09 \mathrm{~h}$ & Estômago & $\begin{array}{l}\text { Acumular os alimentos para que } \\
\text { sofram a ação do suco gástrico. }\end{array}$ & $\begin{array}{l}\text { Boldo } \\
\text { Manjericão }\end{array}$ \\
\hline $09 \mathrm{~h}$ às $11 \mathrm{~h}$ & Baço e Pâncreas & $\begin{array}{l}\text { Relacionar-se com a circulação do } \\
\text { sangue e com a produção de enzimas. }\end{array}$ & $\begin{array}{l}\text { Pariparoba } \\
\text { Sete-sangria }\end{array}$ \\
\hline $11 \mathrm{~h}$ às $13 \mathrm{~h}$ & Coração & $\begin{array}{l}\text { Bombear sangue para todo } 0 \\
\text { organismo. }\end{array}$ & $\begin{array}{l}\text { Alecrim } \\
\text { Pfaffia }\end{array}$ \\
\hline $13 \mathrm{~h}$ às $15 \mathrm{~h}$ & Intestino Delgado & $\begin{array}{l}\text { Os alimentos passam para a } \\
\text { circulação linfática e sanguínea, e a } \\
\text { seguir são distribuídos a todas as } \\
\text { células. }\end{array}$ & $\begin{array}{l}\text { Mil folhas } \\
\text { Funcho }\end{array}$ \\
\hline $15 \mathrm{~h}$ às $17 \mathrm{~h}$ & Bexiga & Receber e acumular a urina. & Cavalinha Malva \\
\hline $17 \mathrm{~h}$ às $19 \mathrm{~h}$ & Rins & $\begin{array}{l}\text { Eliminar as impurezas existentes no } \\
\text { sangue formando a urina. }\end{array}$ & $\begin{array}{l}\text { Quebra-pedra } \\
\text { Carqueja }\end{array}$ \\
\hline $19 \mathrm{~h}$ às $21 \mathrm{~h}$ & Circulação & $\begin{array}{l}\text { Corresponde ao aparelho circulatório } \\
\text { onde possuímos as artérias e veias } \\
\text { que carregam o sangue para todo o } \\
\text { corpo. }\end{array}$ & $\begin{array}{l}\text { Melissa } \\
\text { Hortelã }\end{array}$ \\
\hline $21 \mathrm{~h}$ às $23 \mathrm{~h}$ & $\begin{array}{l}\text { Sistema digestivo, } \\
\text { sistema respiratório e } \\
\text { sistema excretor }\end{array}$ & $\begin{array}{l}\text { Estes três sistemas estão interligados } \\
\text { e são fundamentais para nos manter } \\
\text { saudáveis. Necessitamos de } \\
\text { alimentos para termos energia para } \\
\text { trabalhar e para os órgãos } \\
\text { funcionarem. }\end{array}$ & $\begin{array}{l}\text { Sálvia } \\
\text { Tomilho }\end{array}$ \\
\hline $23 \mathrm{~h}$ às $01 \mathrm{~h}$ & Vesícula Biliar & $\begin{array}{l}\text { Acumular, armazenar e concentrar a } \\
\text { bile. }\end{array}$ & $\begin{array}{l}\text { Bardana } \\
\text { Dente de Leão }\end{array}$ \\
\hline
\end{tabular}

Quadro 5-Gráfico geral das parcelas do Relógio do corpo humano e as Plantas medicinais. 
Monografias Ambientais

REMOANFSM

Fonte: Wermann et. al (2009).

\section{RESULTADOS E DISCUSSÃO}

\subsection{Primeira etapa}

Na primeira etapa, ao responderem à primeira pergunta do questionário: “Quais as plantas medicinais que você conhece?" Foi possível verificar que, das setenta e duas plantas medicinais mencionadas, as vinte e uma mais conhecidas pela comunidade escolar são: Macela, capim cidreira, boldo, funcho, hortelã, babosa, malva, losna, camomila, poejo, cidró, salvia, tansagem, alecrim, quebra-pedra, penicilina, laranjeira, melissa, alcachofra e confrei, conforme mostrado em números absolutos de plantas medicinais na Figura 2.

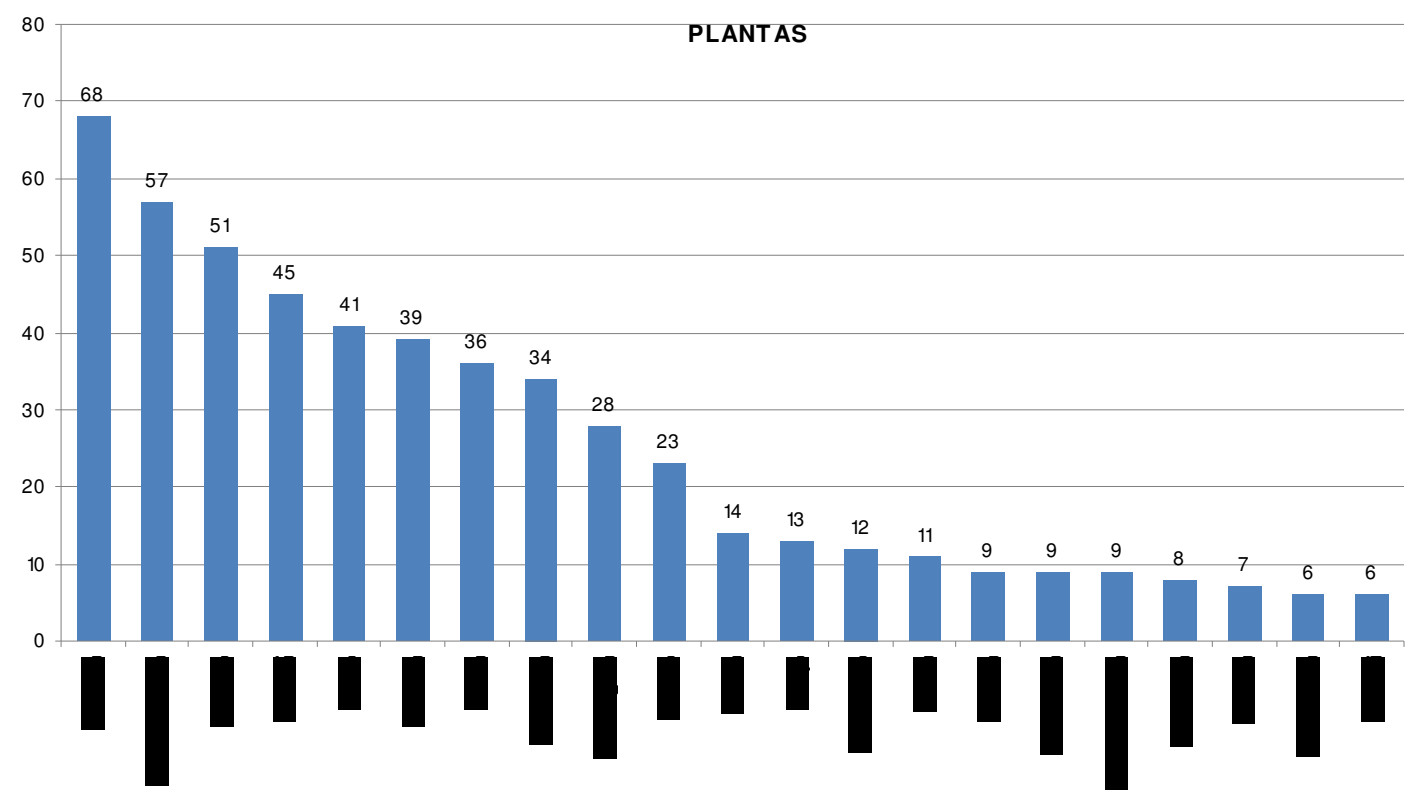

Figura 2 - Plantas medicinais mais conhecidas pela comunidade escolar.

Percebe-se nestes resultados que a maioria das plantas citadas faz parte da relação de plantas medicinais mais usadas no Rio Grande do Sul conforme descreve a EMATER (2008) e que cada povo possui sua própria lista das plantas mais comuns da região em que vive, segundo Caravaca (2000).

Quanto à pergunta: "Você usa plantas medicinais para tratar doenças?", 109 pessoas responderam que sim, apenas uma disse não e outra não opinou conforme o percentual constatado na Figura 2. 


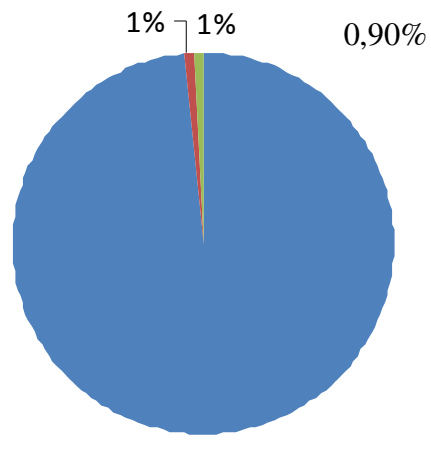

$98 \%$

$0,90 \%$

S im-109

- Não-1

- Não res pondeu-1

$98,20 \%$

Figura 3 - Número de entrevistados que usa plantas para tratar doenças.

Nota-se com esse resultado que o índice de uso dos fitoterápicos é bem significativo, o que confirma a declaração de Simões et al. (1998) quando relata o uso generalizado de plantas na medicina popular. Outro achado interessante que reafirma as informações de Caravaca (2000) é que o hábito do uso de plantas medicinais é uma herança familiar, transmitida de geração a geração, sendo que a maioria dos entrevistados afirmou que aprenderam a utilizá-las com os familiares, conforme mostrado em números absolutos na Figura 4.

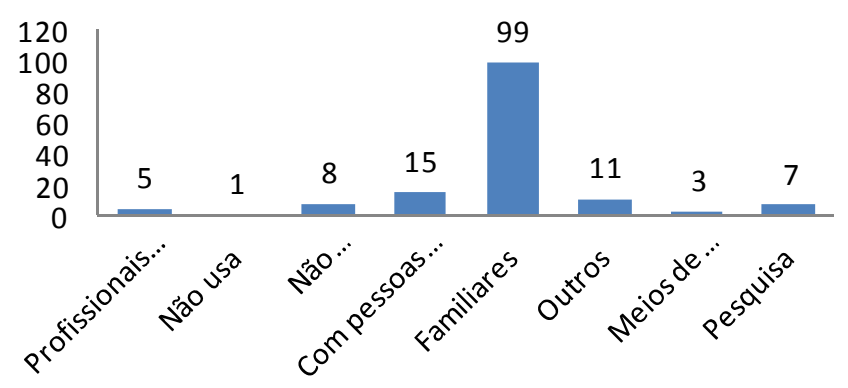

Figura 4 - como aprendeu a utilizar as plantas medicinais.

Percebe-se nas respostas da quarta questão que a credibilidade no resultado esperado é praticamente geral conforme mostrado na Figura 5. 


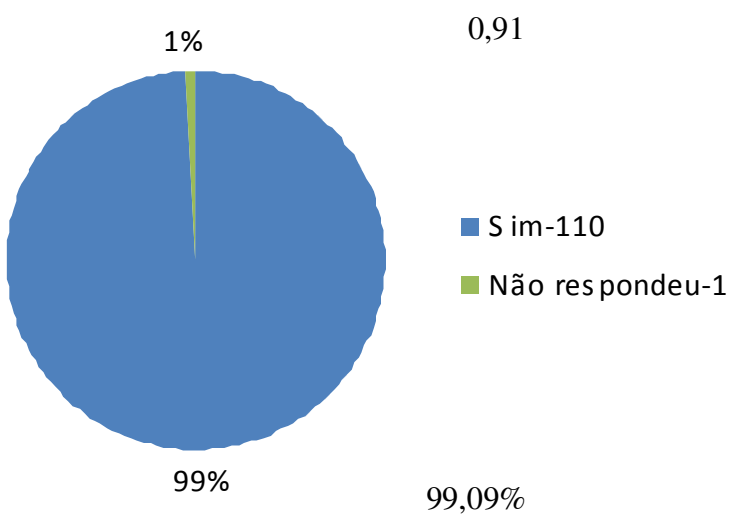

Figura 5 - Resultado no tratamento com plantas medicinais.

Na sexta questão, embora algumas pessoas tenham exposto que fazem uso das plantas medicinais por ser mais barato, $66 \%$ dos entrevistados respondeu que usa as plantas medicinais por achar que não faz mal a saúde, conforme indicado na Figura 6.

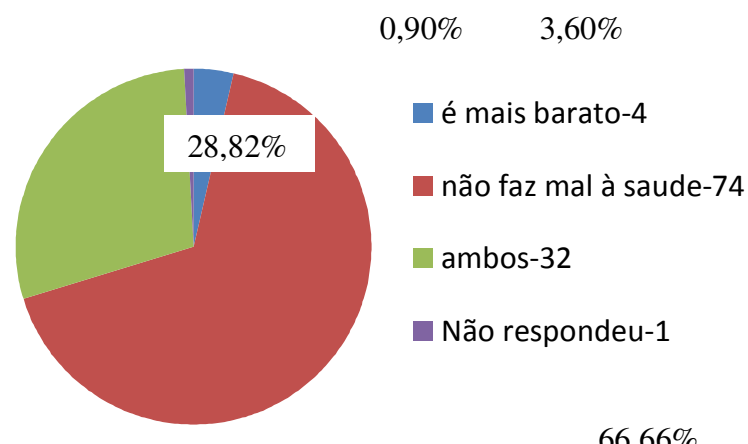

Figura 6 - Motivo pelo qual as plantas medicınaıs sao usadas.

Sendo assim percebe-se a necessidade de melhor informar a comunidade, pois segundo Varella (2010) os brasileiros gostam de pensar que tudo que é natural é necessariamente benéfico sem ao menos se preocuparem com os efeitos indesejáveis.

A pesquisa revela também que o cultivo destas plantas é bem comum conforme se pode constatar no resultado em que em que 82 das 111 pessoas pesquisadas, afirmam adquirir as plantas medicinais no seu próprio quintal e também com os seus vizinhos. Essa integração com os vizinhos tem a ver com a declaração de Morin (2001) quando reforça que a cultura reproduzida em cada indivíduo mantém a identidade humana naquilo que têm de especifico como identidades sociais. O resultado desta questão é demonstrado em valores absolutos na Figura 7. 
Monografias Ambientais

REMOANFSM

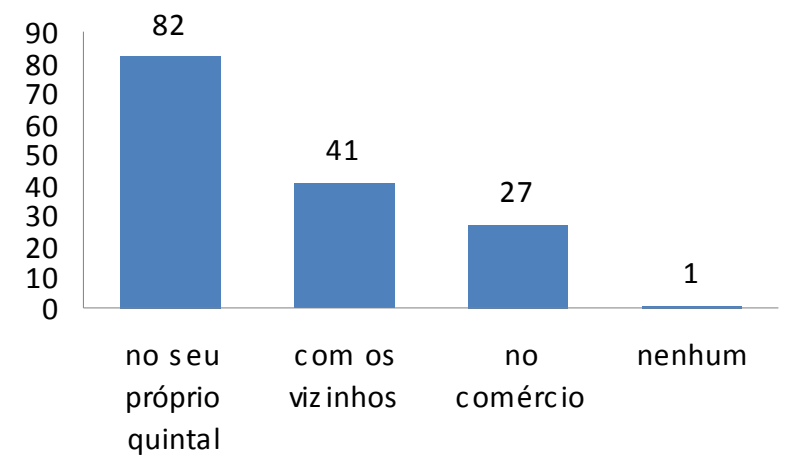

Figura 7 - Local onde são adquiridas as plantas medicinais.

Mas mesmo que, praticamente, a totalidade das pessoas pesquisadas sobre o uso das plantas medicinais tenha respondido afirmativamente na segunda questão, $59 \%$ opinaram que o consumo das plantas diminuiu atualmente, gerando desta forma uma contradição. Esse fato constatado na Figura 8 pode ser indicado para futuras pesquisas.

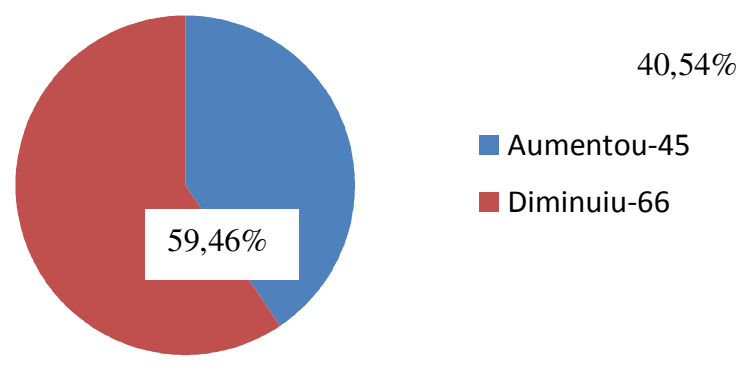

Figura 8 - Opinião sobre o aumento ou declínio no uso de plantas medicinais.

Quanto à pergunta que considera o apoio ao cultivo de uma horta com plantas medicinais na escola da comunidade $97 \%$ das pessoas se declararam favoráveis, sendo possível deduzir que a comunidade concorda com a declaração de Portugal (2007) que a educação é mais efetiva se começada na infância e conforme corrobora Boschilia (2003, p.336): "os pais, a escola, toda a sociedade tem de investir na criança, para que ela cresça consciente da importância de preservar o planeta". É possível constatar esses dados na figura 9.

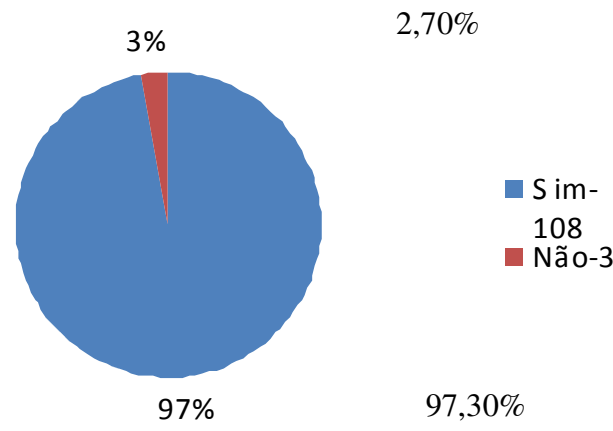


Figura 9 - Apoio ao cultivo de plantas medicinais na Escola.

Em síntese, os dados revelaram que o conhecimento da comunidade escolar da Escola Municipal de Ensino Fundamental Aldo Porto dos Santos sobre plantas medicinais bem como a frequência na sua utilização confirmam que as plantas medicinais continuam fazendo parte da cultura das pessoas. Percebe-se, também que há um apoio significativo da comunidade em cultivá-las na escola, subentendendo-se que existe um interesse dos pais dos alunos em transmitir a cultura a seus filhos.

\subsection{Segunda etapa}

Para a segunda etapa do projeto de estudo foi escolhida a turma de alunos do sexto ano constituída por 20 alunos. A realização da pesquisa científica teve início no mês de agosto/2011 e foram necessárias 8 horas aulas de ciências intercaladas com os conteúdos do Plano de Estudos da Escola. Inicialmente foi distribuído entre os alunos um polígrafo contendo informações que justificam a teoria do relógio do corpo humano. Após o estudo do polígrafo a turma foi dividida em cinco quartetos, sendo que cada grupo pesquisou quatro tipos de plantas medicinais: nome científico, nome popular, parte utilizada, descrição da planta, uso popular e observações. Com os trabalhos de todos os grupos foi montado um livro intitulado "O Relógio das Plantas Medicinais". Título escolhido pelos próprios alunos.

Durante a realização da pesquisa científica, foi sendo construído simultaneamente o "relógio das plantas medicinais", aproveitando-se a oportunidade para associar a prática às aulas teóricas das disciplinas de ciências, matemática, educação artística e ensino religioso, promovendo desta forma a interdisciplinaridade. O relógio foi construído nos fundos do prédio da escola, perto da cozinha. Para tal foram utilizados doze pneus de carro que foram dispostos em torno de um pneu maior, de caminhão, dando assim a forma do relógio conforme mostrado na Figura 10.

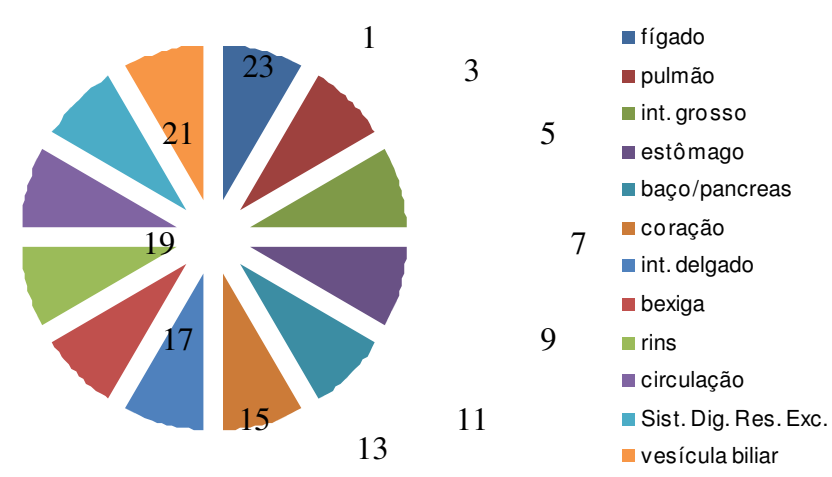

Figura 10 - Representação gráfica do relógio das plantas medicinais.

Em cada pneu de carro foi pintada a sequência dos números naturais ímpares do no. 1 ao no. 23, contendo dois números em cada pneu e entre eles o nome do órgão humano que corresponde ao horário do dia em que o mesmo está em maior atividade. As plantas medicinais foram adquiridas pelos próprios alunos com a orientação e colaboração dos pais e dentro da 
circunferência de cada pneu determinado, foi plantada uma espécie de cada, correspondendo à ação medicinal específica para o órgão do corpo humano indicado no pneu. No pneu do centro foram plantadas mudas de babosa e aloe vera, finalizando desta forma a construção. Na Figura 22 visualiza-se a fotografia da turma do sexto ano junto ao projeto ainda não concluído.

Por meio deste trabalho os alunos, além de aumentarem seus conhecimentos sobre a importância das plantas medicinais fazendo um levantamento sobre as mais conhecidas na comunidade, incluindo a identificação das mesmas, pesquisando sobre suas utilidades e formas corretas de uso, também tiveram a oportunidade de fazer um resgate da cultura local identificando-se com as tradições familiares. Sobretudo, o trabalho com as plantas medicinais apresentou-se como ferramenta para alcançar o objetivo proposto de estimular a Educação Ambiental por meio de associações feitas entre o conhecimento do meio em que vivem e a sensibilização na busca de sua preservação. Igualmente, os alunos puderam desenvolver o espírito de trabalho em equipe organizando grupos de pesquisa e criando estratégias para a aquisição das mudas das plantas medicinais.

\section{CONCLUSÃO}

Avaliando os resultados do projeto e comparando com o objetivo proposto foi possível constatar que na comunidade escolar da EMEF Aldo Porto dos Santos há um conhecimento razoável das plantas medicinais e que as plantas usadas são também as mais utilizadas no Estado, inclusive, são cultivadas nos próprios quintais de suas casas seguindo os costumes passados de geração em geração.

Usando a questão do conhecimento sobre plantas medicinais, não só foi possível identificar a noção da comunidade sobre este assunto como também valer-se do tema como ferramenta para estimular atividades de pesquisa e para informar os alunos e comunidade sobre a importância de saber sobre o emprego correto das plantas medicinais para obter melhor qualidade de vida.

Além do conhecimento já existente na comunidade escolar, foi possível observar, após os trabalhos realizados, uma sensível incorporação das informações obtidas, pois ao fazer o levantamento das plantas medicinais percebeu-se o interesse dos alunos no conhecimento dos seus pais sobre o assunto. Ao realizarem as atividades de pesquisa notou-se o empenho em adquirirem o máximo de informações tanto nos aspectos gerais das plantas como os principais tipos de emprego destas.

Associando a teoria com a prática, os alunos relatavam em sala de aula as receitas caseiras, valorizando dessa forma a cultura local. Quanto ao objetivo de informar sobre o emprego correto das plantas medicinais dando ênfase aos efeitos adversos e toxidez, foi muito propicio, pois percebeu-se, por meio das participações dos alunos e relatos da comunidade escolar, que mesmo sendo uma prática tradicional, ainda há uma certa ignorância quanto ao perigo do uso descuidado das plantas consideradas medicinais.

Isso justifica que a comunidade ainda não está sofrendo a influência das propagandas, conservando desta forma sua cultura, embora a maioria dos entrevistados concorde que houve uma diminuição no uso das plantas, contrariando assim o que informa a literatura sobre o crescente uso de plantas medicinais. A pesquisa mostrou-se positiva, pois $97 \%$ dos participantes 
foram favoráveis ao cultivo das plantas medicinais na Escola sendo confirmado com a participação dos pais dos alunos na construção do "relógio das plantas medicinais".

Também foi possível perceber no decorrer do desenvolvimento do projeto que a Educação Ambiental pode e deve promover a interdisciplinaridade sem a necessidade de préestabelecimentos de disciplinas ou de professores específicos, podendo ser ministrada por todos os professores indistintamente, de forma natural e em doses "homeopáticas", incluindo o assunto, onde puder caber em suas disciplinas, no desenrolar das aulas, conforme aconselha Portugal (1997).

Após o estudo de uma quantidade considerável de bibliografias sobre Educação Ambiental, foi possível perceber sua importância em provocar mudança nos conceitos e nas atitudes das pessoas. Mas também se compreendeu que ela é muito mais efetiva se começada desde cedo, na infância, tanto na educação formal quanto na informal. Em se tratando de educação formal devese ter o cuidado de aliar os novos conhecimentos à cultura da comunidade onde está inserida a escola.

Conclui-se dessa forma que há vários métodos para atingir os objetivos relacionados ao desenvolvimento da Educação Ambiental. Mas essa ação tem melhor resultado quando está apoiada nos interesses comuns e no conhecimento e experiência cultural já existente, como foi, nesse caso, a utilização do conhecimento de plantas medicinais como ferramenta para a realização desse trabalho.

Percebeu-se durante o desenvolvimento das atividades que esse estudo abriu portas que facilitaram o ensino da Educação Ambiental, mostrando assim a importância que esse processo tem em obter continuidade. Para tanto sugere-se que a Política Ambiental seja trabalhada na escola e que se crie uma estrutura para o desenvolvimento de ações com definição de objetivos e metas ambientais. Que neste processo estejam envolvidos não só o professor de ciências, mas também professores de outras disciplinas, de maneira que todos, professores, alunos e comunidade tenham o mesmo pensamento relacionado à Educação Ambiental. Dessa forma, esse trabalho, que serviu como instrumento de acesso à sensibilização ambiental, alcançará resultados ainda mais significativos se obtiver continuidade, fazendo parte das propostas pedagógicas da escola.

\section{REFERÊNCIAS}

ACCORSI, W. R. Medicina natural: Um novo conceito. $n^{\circ} 4,2000$. Vol. 2, p.5

BACKES, P.; IRGANG, B. Árvores do Sul: Guia de identificação \& interesse ecológico.

BALBACH, A. As plantas curam. Itaquaquecetuba, SP: Editora Missionária, 1992.

. A flora nacional na medicina doméstica - Vol.II. 23. ed. Itaquaquecetuba, SP: Editora da Igreja Adventista do Sétimo Dia, [199-].

. As plantas curam. São Paulo: Editora M. V. P., 1967.

BíBLIA. 1993. A Bíblia Sagrada: Antigo e Novo Testamento. Traduzida em português por João Ferreira de Almeida. 2. ed. rev. e atual. no Brasil. São Paulo: Sociedade Bíblica do Brasil, 1993.

BOSCHILIA, C. Minimanual compacto de biologia: teoria e prática. 2. ed. São Paulo: Rideel, 2003. 
BRASIL, Lei de Diretrizes e Bases da Educação. Lei 9.394 de 20 de dezembro de 1996. Alterada pela Lei 10.709 de 31 de julho de 2003.

Lei n. 9.795, de 27 de abril de 1999. Dispõe sobre a educação ambiental, institui a Política Nacional de Educação Ambiental e dá outras providências. Brasília, DF, 27 de abr. de 1999. Disponível em: < http://www.planalto.gov.br/ccivil_03/Leis/L9795.htm>. Acesso em 28 de julho de 2011.

CARAVACA, H. Plantas que curam. Editora Virtual Books Online M\&M Editores Ltda, 2000.

CARVALHO, I.C. de M. Educação ambiental: a formação do sujeito ecológico. São Paulo: Cortez, 2004.

CASTRO, L. O. de; CHEMALE, V. M. Plantas medicinais, condimentares e aromáticas: descrição e cultivo. Guaíba: Agropecuária, 1995.

CHIAVENATO, J. J. O massacre da natureza. 15 ed. São Paulo: Moderna, 1989.

COSTA, L. C. Viva melhor! : com a medicina natural. . Itaquaquecetuba, SP: Missionária, 1996.

DAJOZ, R. Ecologia geral. Petrópolis, São Paulo: Vozes, 1973.

DIAS, G. F. Educação ambiental: princípios e práticas. 9 ed. São Paulo: Gaia, 2004.

EMATER/RS. FR70.000. JUL2008.

FERNANDES, J. L. M. Ervas medicinais: o poder da plantas. V.10. 2005. AFUBRA: Associação dos Fumicultores do Brasil, 2005, $15 \mathrm{p}$.

FERNANDES, S. M. Básico de plantas medicinais, condimentares e aromáticas: manual de treinamento. Porto Alegre: SENAR/AR-RS, 2003.

FREIRE, P. Pedagogia da autonomia. 36 ed. São Paulo: Paz e Terra, 2007.

FRANCO, I. J. (Pe.) Ervas e plantas: A medicina dos simples. [S.I.: s.n.]: 1997.

FRANCO, I. J. (Pe.); FONTANA, V. L. Ervas e plantas: A medicina dos simples. 9. ed. Erexim, RS: Livraria Vida Ltda., 2004.

GONÇALVES, J. A. Meio ambiente: a vida em jogo. São Paulo: Salesiana, 2007.

LAUTERT, C.J.; KLEINÜBING, L. P.; ZENKER, L. M.; CARVALHO, T. Q. de (organizadores). A educação ambiental inovando a gestão. Porto Alegre, RS: Kraskin e A+, 2006.

LEIS, H.R. A modernidade insustentável: as criticas do ambientalismo à sociedade contemporânea. Petrópolis, RJ: Vozes, 1999.

LEITE, M. Meio ambiente e sociedade. São Paulo: Ática, 2005.

LORENZI, H.; MATOS, M. F. J. de A. Plantas medicinais no Brasil - nativas e exóticas. São Paulo: Instituto Plantarum, 2002.

Plantas medicinais no Brasil - nativas e exóticas. 2. ed. São Paulo: Instituto Plantarum, 2008.

MATOS, F. J. A. Farmácias vivas. 2. ed. Fortaleza: EUFC, 1994.

MINC, C. Ecologia e cidadania. 2. ed. São Paulo: Moderna, 2005. 
MORIN, E. Os sete saberes necessários à educação do futuro. 3 ed. São Paulo: Cortez; Brasília, DF: UNESCO, 2001.

NEVES, E.; TOSTES, A. Meio ambiente: aplicando a Lei. Petrópolis: Vozes, 1992.

NOVELLI, J. L.; DELLUCA, A. F.; PIAZZA, E.; FERNANDES, R. F.; DARÓS, G. E.; FERNANDES, M. E.; COLOMBO, A. M.; COSTA, B.; VITALI, D. M.; CICHELLA, F.; BOIT, F. P. da; RESENDES, L. M.; SPILLERE, R. Ç.; MICHELS, R. A.; ROSA, S. S. da; JENOVÊNCIO, T. C.; DAMIANI, T. R. Educação ambiental no Bairro da Juventude. II Fórum ambiental da Alta Paulista. Outubro, 2006. Disponível em: < http://www.amigosdanatureza.org.br.EA-23.pdf > Acesso em: 29 de setembro de 2011.

Parâmetros curriculares nacionais: introdução aos parâmetros curriculares nacionais / Secretaria de Educação Fundamental. - $\quad$ Brasília: MEC/SEF, 1997. 126p. Disponível em < http://portal.mec.gov.br/seb/arquivos/pdf/livro01.pdf> acesso em 28 de julho de 2011.

PORTUGAL, G. Educação ambiental desde a base. HP - Gil Portugal. Março/1997. Disponível em: < http://www.gpca.com.br/gil/art24.html>. Acesso em: 28 de setembro de 2011.

. Educação ambiental para todos. HP - Gil Portugal. Julho/1998 Disponível em: < http://www.gpca.com.br/gil/art29.htm >. Acesso em: 28 de setembro de 2011.

PUTZKE, J. Guia prático para estudos em biodiversidade: nível fundamental e médio. Porto Alegre, RS: Ed. do Autor, 2006.

REBOUÇAS, F. Conceito de meio ambiente. Infoescola: navegando e aprendendo. Fevereiro/2009. Disponível em: < http://www.infoescola.com/geografia/conceito-de-meio-ambiente/

>. Acesso em: 28 de setembro de 2011.

RICARDO, B.; CAMPANILI, M. Almanaque Brasil Sócio Ambiental. São Paulo, SP: Takano Editora Gráfica, 2004.

RIGOTA, M., ESMÉRIO, M., (Orgs). Um olhar sobre a educação ambiental. Porto Alegre: Secretaria de Estado da Educação/RS, 2002.

ROSA, A. V. Agricultura e meio ambiente. São Paulo: Atual, 1998.

RUDDER, E. A. M. C. de. Guia compacto das plantas medicinais. São Paulo: Rideel, 2002.

SCARLATO, F. C.; POTIN, J. A. Do nicho ao lixo: ambiente, sociedade e educação. 18 ed. São Paulo: Atual, 2009.

SCHIPPER, L. P. (editora executiva). Segredos e virtudes das plantas medicinais. Rio de Janeiro, RJ: Reader's Digest Brasil Ltda., 1999.

SILVEIRA, I. M. M. O conhecimento popular sobre o papel curador das plantas e suas possibilidades para a educação e a escola. 2005. 55f. Monografia (Pós-graduação em gestão educacional) - Universidade Federal de Santa Maria, Santa Maria, 2005.

SILVEIRA, Pedro (diagramador). Como usar produtos naturais: para uma vida saudável. Santa Maria, RS: Pallotti, [199-].

SIMÕES, C. M. O. MENTZ, L. A.; SCHENKEL, E. P.; IRGANG, B. E.; STHMANN, J. R. Plantas da medicina popular no Rio Grande do Sul. Porto Alegre, RS: Editora da Universidade UFRGS, 1998.

SOARES, C. A. A cura que vem dos chás. 2. ed. Petrópolis, RJ: Vozes, 2007.

SOUZA, N. M. e. Educação ambiental: dilemas da prática contemporânea. Rio de Janeiro: Thex Ed.: Universidade Estácio de Sá, 2000. 
VEIGA JUNIOR, V. F.; PINTO, A. C.; MACIEL, M. A. M. Plantas medicinais: cura segura? Quím. Nova vol.28 no. 3 São Paulo May/June 2005. Disponível em: < http://www.scielo.br/scielo. php?pid=S0100-40422005000300026\&script=sci_arttext> acesso em: 28/07/2011.

ZATTA, Ir. M.; DESTEFANI, Ir. G.; HAAS, Ir. S. B.; SPANENBERG, M. Receitas da sabedoria popular. [S.I.: s.n.]: 1988.

ZIEGER, M. Ecopedagogia: o remo e o rumo da educação. Tramandaí, RS: Ísis, 2004.

UNESCO-PNUMA. Educación para un futuro sostenible: una visión transdisciplinaria para una acción concertada. Documento preparatório para a Conferência Internacional de Educação Ambiental em Thessaloniki, Grécia, dezembro de 1997.

WERMANN, A. M.; VelLOSO, C. C.; ROSSINI, M. I. P.; POLESI, R. G. Horto medicinal relógio do corpo humano: qualificação da experiência de sistematização de Putinga, RS. Porto Alegre: EMATER/RS-ASCAR, 2009.

WERTHEIN, J.; CUNHA, C. Fundamentos para uma nova educação. Brasília: UNESCO, 2000.

VARELLA, D. Ervas medicinais: os conselhos de Drauzio Varella. [entrevista disponibilizada em 13 de agosto de 2010]. Entrevistadora: Cristiane Segatto. Porto Alegre: Revista Época. Ed. Globo, 2010. Disponível em: <http://revistaepoca.globo.com/Revista/Epoca/0,,EMI162899-15230,00-

ERVAS\%20MEDICINAIS\%200S\%20CONSELHOS\%20DE\%20DRAUZIO\%20VARELLA.html>. Acesso em: 27/07/2011 